\title{
Taxonomic notes on the genus Teucholabis Osten Sacken, 1860 (Diptera, Limoniidae) of Japan
}

\section{Таксономические замечания о роде Teucholabis Osten Sacken, 1860 (Diptera, Limoniidae) Японии}

\author{
D. Kato \\ A. Като \\ Biosystematics Laboratory, Graduate School of Integrated Sciences for Global Society, Kyushu University, 744 Motooka, Fukuoka \\ 819-0395 Japan. E-mail: hehemanpuldoa.d4@gmail.com. \\ Лаборатория биосистематики, Высшая школа интегрированных наук для глобального общества, Университет Кюсю, \\ Фукуока 819-0395 Япония.
}

Key words: Diptera, Limoniidae, Teucholabis, new record, Japan, taxonomy, male genitalia.

Ключевые слова: Diptera, Limoniidae, Teucholabis, новые находки, Япония, таксономия, гениталии самцов.

\begin{abstract}
Japanese species of the genus Teucholabis Osten Sacken, 1860 are revised. Teucholabis (T.) inornata Riedel, 1918 is newly recorded from Japan and T. (Paratropesa) inouei Alexander, 1955 is transferred to the subgenus Euparatropesa Alexander, 1947. Images of external appearance and wings, and drawings of male genitalia of the Japanese species are provided Male genitalia of $T$. (T.) inornata and $T$. (T.) iriomotensis Alexander, 1935 are illustrated for the first time
\end{abstract}

Резюме. Ревизованы японские виды рода Teucholabis Osten Sacken, 1860. Teucholabis (T.) inornata Riedel, 1918 г. впервые зарегистрирован в Японии. T. (Paratropesa) inouei Alexander, 1955 перенесён в подрод Euparatropesa Alexander, 1947. Приводятся изображения внешнего вида и крыльев, а также гениталий самцов японских видов. Впервые изображены гениталии самцов $T$. (T.) inornata и T. (T.) iriomotensis Alexander, 1935.

\section{Introduction}

Teucholabis Osten Sacken, 1860 is a genus of the subfamily Chioneinae and includes 309 species in the world (4 species in the Palaearctic, 7 species in the Nearctic, 242 species in the Neotropic, 8 species in the Afrotropic, 36 species in the Oriental, 15 species in the Australasian / Oceanian Regions), which are classified into four subgenera: Euparatropesa Alexander, 1947 (18 species); Euteucholabis Alexander, 1947 (2 species); Paratropesa Schiner, 1866 (13 species); Teucholabis (277 species) [Oosterbroek, 2019].

In the Palaearctic Region, immature stages of two species of the genus, T. (Eup.) esakii Alexander, 1924 and T. (T.) yezoensis Alexander, 1924 are known, and were found among bast fibers in rather humidified woods of various species [Krivosheina, 2009].

In Japan, four species of the genus have been recorded: T. (Eup.) esakii; T. (P.) inouei Alexander, 1955; T. (T.) iriomotensis Alexander, 1935; T. (T.) yezoensis [Nakamura, 2014; Oosterbroek, 2019]. In this study, Japanese species of the genus are revised, with images of their wings and habitus and drawings of their male genitalia, as I examined their type specimens and additional ones from various sites of Japan.

\section{Materials and Methods}

The samples were collected by using insect nets or malaise traps (MT), and are preserved in the Biosystematic Laboratory, Kyushu University, Japan (BLKU). I also examined specimens in the U.S. National Museum of Natural History, Smithsonian Institution, Washington, D.C., USA (USNM), which were identified by C.P. Alexander. Overall descriptions of the species were based on the observations through a dissecting microscope, ZEISS Stemi 305. Male genitalia were boiled in a solution of $10 \% \mathrm{KOH}$ for several minutes, then rinsed in a solution of $70 \%$ ethanol with $3 \%$ acetic acid for neutralization, and transferred to glycerol for examination and drawing. The treated genitalia were preserved in genitalia tubes filled with glycerol and the tubes were pinned below the body remains. Drawings were made with the microscope using an ocular micrometer and grid papers. Terminology mainly follows Cumming and Wood [2017]. General distributions of species were referred to Oosterbroek [2019].

\section{Taxonomy}

\section{General description of Japanese species of Teucholabis}

Head with eye dichoptic, about three times as wide as scape, ventral side very close to each other; rostrum cylindrical, about half as long as remainder of head; antenna about 1.5 times as long as head; scape cylindrical, about half length of pedicel; pedicel and basal segments of flagellum globular, distal flagellomeres long oval; palpus dark brown, 4-segmented; thorax with prescutal pit very small; tuberculate pit absent; meron weakly developed, mid and hind coxae separated by about 
twice width of coxa; wing with $\mathrm{R}_{2}$ present (subgen. Euparatropesa) or absent (subgen. Teucholabis); crossvein r-r at or slightly distal to fork of Rs; crossvein r-m present; cell d closed; legs with femora weakly swollen on distal parts; tip of hind tibia of male often weakly widened and flat; abdomen with sternites 5 and 7 usually bearing roundish lobes near middle in male; male genitalia not rotated, tergite 9 situated dorsally; gonostyli subterminal.

\section{Teucholabis (Euparatropesa) esakii Alexander, 1924 Figs 1-4.}

Paratropesa esakii Alexander, 1924: 591. Type locality: Japan, Hokkaido, Sapporo, Maruyama.

Teucholabis (Euparatropesa) esakii: Alexander [1947: 378]; Nakamura [2014: 35]; Oosterbroek [2019].

Material. Paratypes: Japan: [Hokkaido] $20^{7} \sigma^{7}$, Sapporo, Maruyama, 17.VIII.1922, T. Esaki leg. (USNM). Non-types: JAPAN: [Hokkaido] 10, 19, Eniwa-shi, Banjiri, Izari-kawa River, Alt. 180 m, 2.IX.2018, D. Kato leg. (BLKU); [Honshu] $10^{7}$, Aomori, Hirosaki-shi, Ichinowatari-Washinosu, Alt. 205 m; 5.IX.2013, D. Kato leg. (BLKU); 10, 1 , , same data as previous except A. Ogawa leg.; 10 1 , 1, Aomori, Hirosaki-shi, Koguriyama, Inekari-sawa River, Alt. 170 m, 10.IX.2013, D. Kato leg. (BLKU); 19, Echigo (Niigata), Kurokawa, 14.VII.1955, K. Baba leg. (USNM); 10 36 m, 6-25.VI.2015, S. Shimizu leg. (MT / BLKU); 1우, Tottori, Yazu-chф, Mt. Фgino-sen, Alt. 900 m, 17.IX.2014, D. Kato leg. (BLKU).

Description. Male (Figs 1-4). Body length 5.2-7.0 mm, wing length $6.0-7.5 \mathrm{~mm}$.

Head dark brown to black, posterior end yellowish, anterior part of vertex weakly dusted with gray pruinosity; antenna dark brown, scape brown, bases of pedicel and flagellomere 1 yellowish.

Thorax with pronotum yellow, darkened at anterior margin and weakly so on middle part on antepronotum; mesonotum mainly shiny black; prescutum with yellow area above humeral region and smaller ones at posterolateral corner and middle of posterior end; scutum yellow between scutal lobes and at posterior and inner margins of scutal lobe; scutellum entirely yellow; pleura mainly yellow, shiny black on anepisternum, laterotergite, and ventral side of katepisternum. Wing (Fig. 2) tinged with yellowish gray, stigma roundish and dark brown; smaller dark spots at crossvein Sc-r, origin of Rs, $\mathrm{R}_{2}$, tip of $\mathrm{A}_{1}$; indistinctly dark, tiny spots at tips of veins reaching wing margin; narrow dark seams along cord, outer end of cell d, and wing margin at tip. Legs with coxae, trochanters, and femora yellow, dark brown on about distal half of fore femur and about distal 1/4 of mid and hind femora; tibiae dusky yellow, distal $1 / 3$ gradually darkened toward tips, bases narrowly darkened, tip of hind tibia weakly wid-

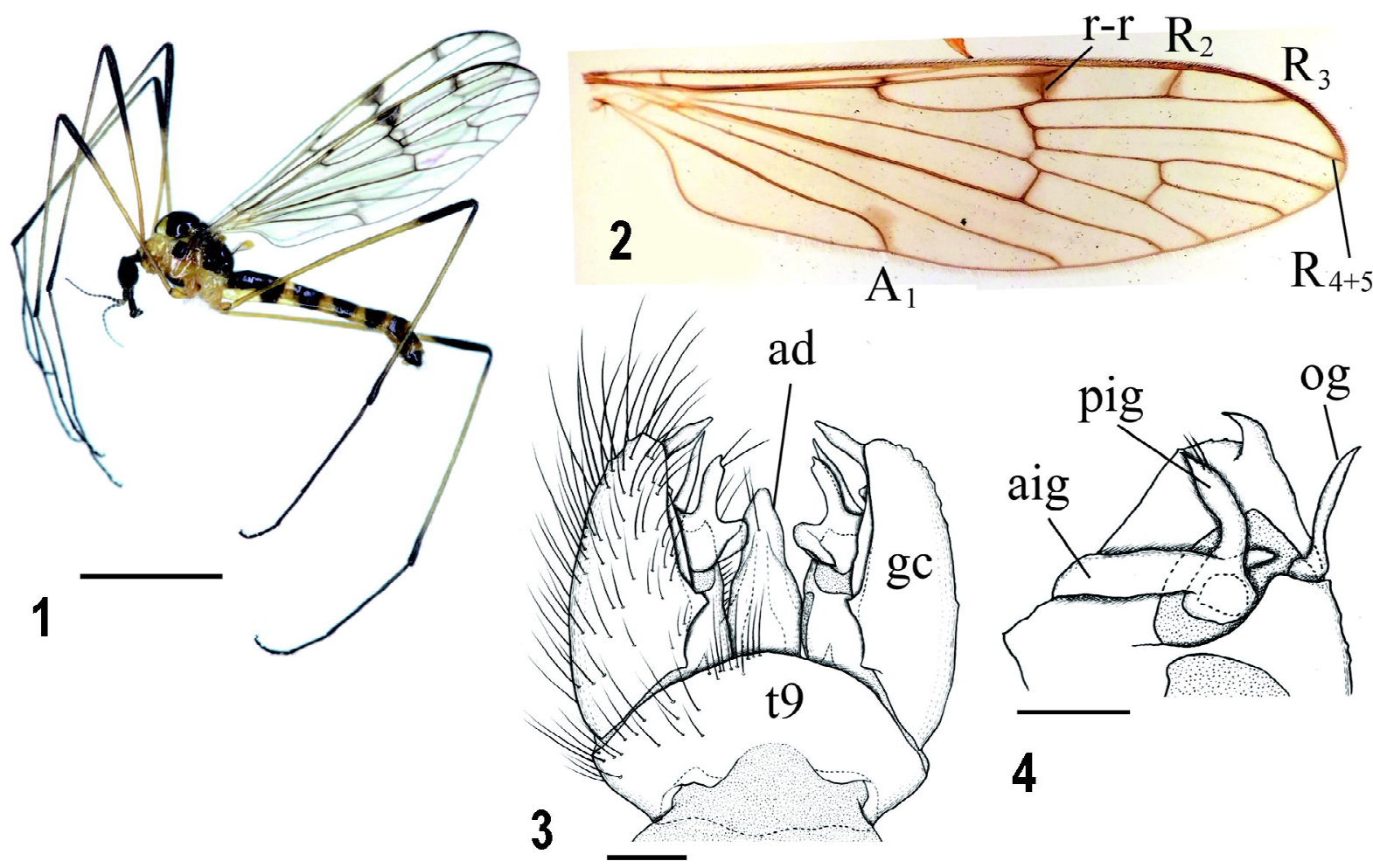

Figs 1-4. Teucholabis (Euparatropesa) esakii Alexander, 1924: 1 - habitus, male; 2 - wing; 3 - male genitalia, dorsal view; 4 - gonocoxite, inner surface (left = dorsal). Abbreviation: ad - aedeagus; aig - anterior lobe of inner gonostylus; gc - gonocoxite; og - outer gonostylus; pig - posterior lobe of inner gonostylus; t9 - tergite 9 . Scale bar: $1-3 \mathrm{~mm}, 3,4-0.1 \mathrm{~mm}$.

Pис. 1-4. Teucholabis (Euparatropesa) esakii Alexander, 1924: 1 - внешний виА, самец; 2 - крыло; 3 - гениталии самца, вид сверху; 4 - гонококсит, внутренняя поверхность (слева = дорсально). Сокрашения: ad - эдеагус; aig - передняя доля внутреннего гоностиля; gc - гонококсит; og - наружный гоностиль; pig - задняя доля внутреннего гоностиля; $t 9-$ 9-й тергит. Масштаб: $1-3$ мм, 3, 4-0,1 мм. 
ened and flat; tarsi dark brown, often brownish at bases. Halter yellow on knob, dark brown on stem.

Abdomen with tergites shiny dark brown to black, caudal margins of segments 2 to 7 narrowly yellow, anterior margins of segments 3 to 6 more widely yellow; sternites yellow, with dark band on posterior half of each of segments 2 to 3 , and near middle of each of segments 4 to 5 ; sternite 5 with hairy roundish swelling on dark area; sternite 6 with pair of rows of setae; sternite 7 with short conical lobe at middle. Male genitalia (Figs 3-4) yellow on segment 9, dark brown on gonocoxite; tergite 9 arched at caudal margin; gonocoxite with claw-shaped lobe at tip, curved dorsally, dorsal margin of gonocoxite angulated near base; outer gonostylus slender rod-shaped, almost straight, acute at tip; inner gonostylus bilobed, anterior lobe blade-shaped, straight, posterior lobe smaller, about $2 / 3$ length of anterior one and slightly narrower than anterior one, weakly curved, acute at tip, with two setae near tip; aedeagus finger-shaped in dorsal view, middle of ventral part with projection directed posteriorly, tip of this projection not reaching at level of tip of aedeagus.

Female. Body length 6.7-8.9 mm, wing length 5.8-7.0 $\mathrm{mm}$. Resembling male in general appearance. Thorax with darkening on ventral side of katepisternum sometimes weakened; hind tibia not widened at tip; abdomen with dark bands on sternites strongly narrowed or interrupted at centers, sternites 6 to 7 with dark spot near middle of lateral margin of each segment; roundish swellings absent. Ovipositor slender; tergites 8 to 9 yellow, tergite 10 cylindrical, dark brown on distal $2 / 3$; cercus amber color, slightly longer than tergite 10 , weakly upcurved, subacute at tip; sternite 8 small, yellow on basal part, dark brown distally; hypogynial valve dark brown, weakly upcurved, basal part about as wide as sternite 8 , tip ending at level of distal $1 / 3$ of cercus.
Distribution. Japan (Hokkaido, Honshu); Russian Far East.

\author{
Teucholabis (Euparatropesa) inouei \\ Alexander, 1955 \\ Figs $5-8$.
}

Teucholabis (Paratropesa) inouei Alexander, 1955: 374. Type locality: Japan, Honshu, Tokyo, Mt. Takao-san.

Teucholabis (Paratropesa) inouei: Nakamura [2014: 35]; Oosterbroek [2019].

Material. Holotype: 10 of Tokyo), Mt. Takao, 13.V.1950, H. Inoue leg. (USNM). Non-types: JAPAN: [Honshu] 10, Ishikawa, Kaga-shi, Mt. Kariyasu-yama, 30.V.2002, K. Esaki leg. (MT/BLKU); 10', Niigata, Nagaoka-shi, Urase-machi, Alt. 35 m, 14-26.V.2015, S. Shimizu et al. leg. (MT/BLKU).

Description. Male (Figs 5-8). Body length 7.2-9.0 mm, wing length $8.5-9.0 \mathrm{~mm}$.

Head dark brown to black, anterior part of vertex weakly dusted with gray pruinosity; antenna dark brown, scape brown, ventral side of scape and base of pedicel yellowish.

Thorax with pronotum yellow, darkened at anterior margin and weakly so on middle part of antepronotum; mesonotum mainly shiny black, with long yellow area above humeral region, middle of transverse suture and outer-posterior corner of scutal lobe yellowish; pleura mainly shiny black, yellow on propleura, katepimeron, metapleura, and dorsal part of katepisternum; posterior part of yellow part of katepisternum sometimes weakly infuscated. Wing (Fig. 6) tinged with gray, stigma roundish and dark brown; smaller dark spots at crossvein Sc-r, origin of Rs, $\mathrm{R}_{2}$, and tip of $\mathrm{A}_{1}$; distinct dark seams along cord and outer end of cell d; wing tip distal to level of middle of $\mathrm{M}_{1+2}$ infuscated; cell cua weakly infuscated near tip. Legs with

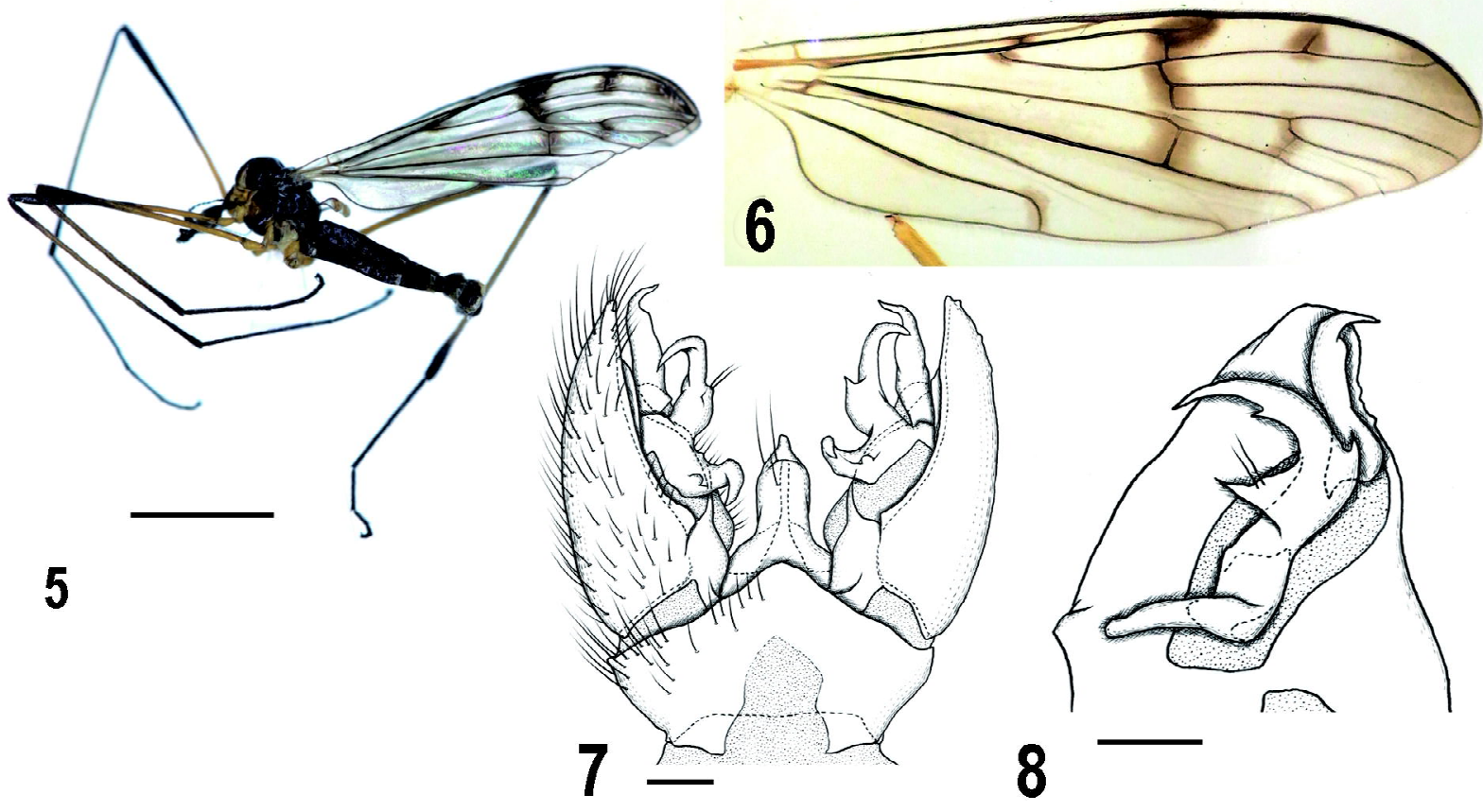

Figs 5-8. Teucholabis (Euparatropesa) inouei Alexander, 1955: 5 - habitus, male; 6 - wing; 7 - male genitalia, dorsal view; $8-$ gonocoxite, inner surface (left $=$ dorsal). Scale bar: $5-3 \mathrm{~mm}, 7,8-0.1 \mathrm{~mm}$.

Рис. 5-8. Teucholabis (Euparatropesa) inouei Alexander, 1955: 5 - внешний вил, самец; 6 - крыло; 7 - гениталии самца, вид сверху; 8 - гонококсит, внутренняя поверхность (слева = дорсально). Масштаб: $5-3$ мм, 7, $8-0.1$ мм. 


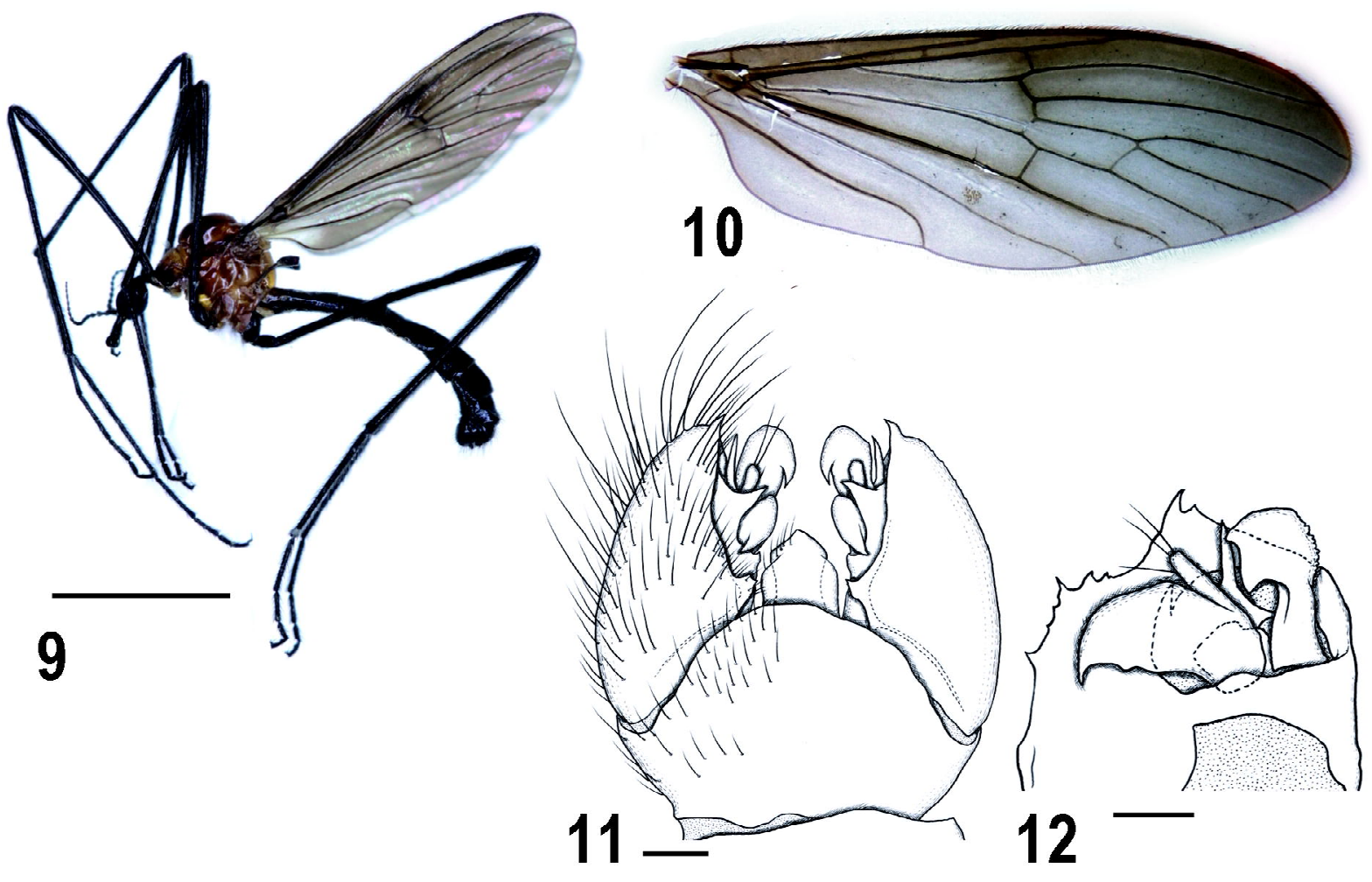

Figs 9-12. Teucholabis (Teucholabis) inornata Riedel, 1918: 9 - habitus, male; 10 - wing; 11 - male genitalia, dorsal view; $12-$ gonocoxite, inner surface (left $=$ dorsal). Scale bar: $9-3 \mathrm{~mm}, 11,12-0.1 \mathrm{~mm}$.

Pис. 9-12. Teucholabis (Teucholabis) inornata Riedel, 1918: 9 - внешний виА, самец; 10 - крыло; 11 - гениталии самца, виА сверху; 12 - гонококсит, внутренняя поверхность (слева = дорсально). Масштаб: $9-3$ мм, 11, $12-0,1$ мм.

coxae, trochanters, and femora yellow, dark brown on about distal half of fore femur and about distal $1 / 4$ of mid and hind femora; tibiae dusky yellow, basal $1 / 5$ and distal $1 / 3$ gradually darkened toward bases and tips, respectively, tip of hind tibia weakly widened and flat; tarsi dark brown. Halter yellow on knob, dark brown on stem.

Abdomen shiny black, caudal margins of segments 2 or 3 to 7 or 8 narrowly yellow; sternite 5 with hairy roundish swelling on posterior half; sternite 6 with pair of rows of setae; sternite 7 with very low, roundish swelling at middle. Male genitalia (Figs 7-8) with tergite 9 triangular at caudal margin and rounded at tip; gonocoxite rounded at tip, dorsal margin of gonocoxite weakly produced near base; outer gonostylus sickle-shaped, distal $1 / 5$ strongly narrowed and curved ventrally, tip acute; inner gonostylus bilobed, anterior lobe sinuous, rod-shaped on distal part, with weak swelling near middle of dorsal surface, posterior lobe large and crab claw-shaped, posterior part slender, gently curved, with small spines at posteroventral corner and middle of anterior margin, anterior part short and wide, about $1 / 2$ as long as dorsal part, with two setae near middle of posterior margin; aedeagus roughly finger-shaped, middle of ventral part strongly produced posteriorly into pointed lobe, tip of this projection extending beyond tip of aedeagus.

Female. Unknown.

Distribution. Japan (Honshu).

Remarks. This species was described in the subgenus Paratropesa, but the venation apparently shows the characters of the subgenus Euparatropesa $\left(\mathrm{R}_{2}\right.$ and crossvein $\mathrm{r}-\mathrm{m}$ present). Therefore this species is treated in the latter subgenus in this study.

\section{Teucholabis (Teucholabis) inornata Riedel, 1918}

Figs 9-12.

Teucholabis inornata Riedel, 1918: 317. Type localities: Taiwan, Taihorinsho and Tapani.

Teucholabis (Teucholabis) inornata: Oosterbroek [2019].

Material. Non-types: Japan: [Nansei Islands] 10', Okinawa-jima Is, Kunigami-son, Yona, Mt. Fuenchiji-dake, Alt. $250 \mathrm{~m}$, 4.VIII.2016, D. Kato leg. (BLKU); $20^{2} \mathrm{O}^{2}$, 1웅, Iriomotejima Is, Haeminaka-Haemi, Alt. 170-230 m, 19.V.2016, D. Kato leg. (BLKU); 10 , 19, Iriomote-jima Is, Iriomote, Funauki, Alt. 7-100 m, 14.V.2016, D. Kato leg. (BLKU). TAIWAN: $10^{7}$, further details of collecting site and date not given, H. Sauter leg. (USNM).

Description. Male (Figs 9-12). Body length 5.6-8.4 mm, wing length $5.2-7.5 \mathrm{~mm}$.

Head black, often brownish at posterior end, anterior part of vertex weakly dusted with gray pruinosity; antenna dark brown to black.

Thorax orange to brownish orange, antepronotum sometimes slightly darker anteriorly or at anterior margin, anterior part of prescutum with dark narrow stripe at middle. Wing (Fig. 10) strongly tinged with black, still darker along anterior margin and anterior part of cord. Legs with coxae orange to brown on fore and mid pairs, sometimes darkened basally or entirely, hind pair dark brown to black; succeeding segments dark brown to black. Halter dark brown, base of stem pale.

Abdomen dark brown to black, tergite 1 orangish anteriorly; sternite without distinct swelling. Male genitalia (Figs 1112 ) with tergite 9 strongly and roundly produced posteriorly at caudal margin; gonocoxite with short lobe at middle of apical 
margin, bearing spine(s) at tip, dorsal margin of gonocoxite serrate on middle part and with short lobe near base, dorsal side of margin surrounding gonostyli produced ventrally into pointed lobe; outer gonostylus rougly ax-shaped, rounded at posterior margin, distal part of ventral margin scabrous, distal part of dorsal margin weakly bilobed, posterior point directed dorsally, ventral one directed anteriorly; inner gonostylus trilobed, anterior lobe wide beak-shaped, sharply pointed and curved anteriorly at extreme tip, middle lobe rod-shaped, about half as long as anterior one, obtuse at tip, with three setae at tip, posterior lobe spine-shaped, about as long as middle one; aedeagus stout finger-shaped in dorsal view, ventral margin roundly and widely produced ventrally.

Female. Body length $6.8-8.7 \mathrm{~mm}$, wing length $6.0-7.2$ $\mathrm{mm}$. Resembling male in general appearance. Thorax slightly darker than male, brown. Ovipositor dark brown, stout basally; tergite 10 roundish in dorsal view; cercus reddish brown, dark at base, about 1.5 times as long as tergite 10 , strongly upcurved, acute at tip; sternite 8 large, about $2 / 3$ as long as hypogynial valve; hypogynial valve brownish distally, almost straight, basal part much narrower than sternite 8 , tip ending at level of distal $1 / 2$ of cercus.

Distribution. Japan (Nansei Islands: Okinawa-jima Is.; Iriomote-jima Is.); Taiwan.

Remarks. It is the first record of this species from Japan.

\section{Teucholabis (Teucholabis) iriomotensis Alexander, 1935} Figs $13-16$.

Teucholabis (Teucholabis) iriomotensis Alexander, 1935: 218. Type locality: Japan, Nansei Islands, Iriomote Is.

Teucholabis (Teucholabis) iriomotensis: Nakamura [2014: 36]; Oosterbroek [2019].
Material. Holotype: 107, Japan: Nansei Islands, Iriomote Is., 20.VIII.1934, J.L. Gressitt leg. (USNM). Non-types: JAPAN [Nansei Islands] 207, 2\%, Iriomote Is., Haeminaka-Haemi, Alt. 170-230 m, 19.V.2016, D. Kato leg. (BLKU).

Description. Male (Figs 13-16). Body length 6.0-6.8 $\mathrm{mm}$, wing length $5.3-6.0 \mathrm{~mm}$.

Head black, anterior part of vertex dusted with gray pruinosity; antenna black, brownish on basal three segments.

Thorax with antepronotum shiny brown, darkened at anterior margin and yellowish at lateral margin, postpronotum dull yellow; mesonotum mainly shiny black; prescutum with yellow area above humeral region and smaller ones at posterolateral corner and middle of posteror end; scutum yellow between scutal lobes and at posterior and inner margins of scutal lobe; scutellum entirely yellow; pleura mainly yellow, shiny black on laterotergite and anterodorsal part of anepisternum, weakly dark on ventral side of katepisternum. Wing (Fig. 14) tinged with grayish brown, stigma roundish, dark brown, anterior part of cord slightly seamed with brown; short branch of $\mathrm{R}_{2}$ sometimes present. Legs with coxae and trochanters yellow; femora black, basal $2 / 5$ of fore and mid pairs yellow; succeeding segments black, tip of hind tibia weakly widened and flat. Halter dark brown.

Abdomen with tergites shiny dark brown to black; sternites mainly yellow, each segment of sternites 2-4 with dark area on lateral side of posterior part, sternite 5 largely darkened on center, with hairy roundish swelling at middle; sternite 6 with pair of rows of setae; sternite 7 with weak roundish swelling on center. Male genitalia (Figs 15-16) yellow on segment 9 , dark brown on gonocoxite; tergite 9 arched at caudal margin; gonocoxite with claw-shaped lobe at tip, curved dorsally, bearing small spine at middle of posterior margin, dorsal margin of gonocoxite with small projection near base; outer gonostylus slender rod-shaped, acute and weakly curved ven-

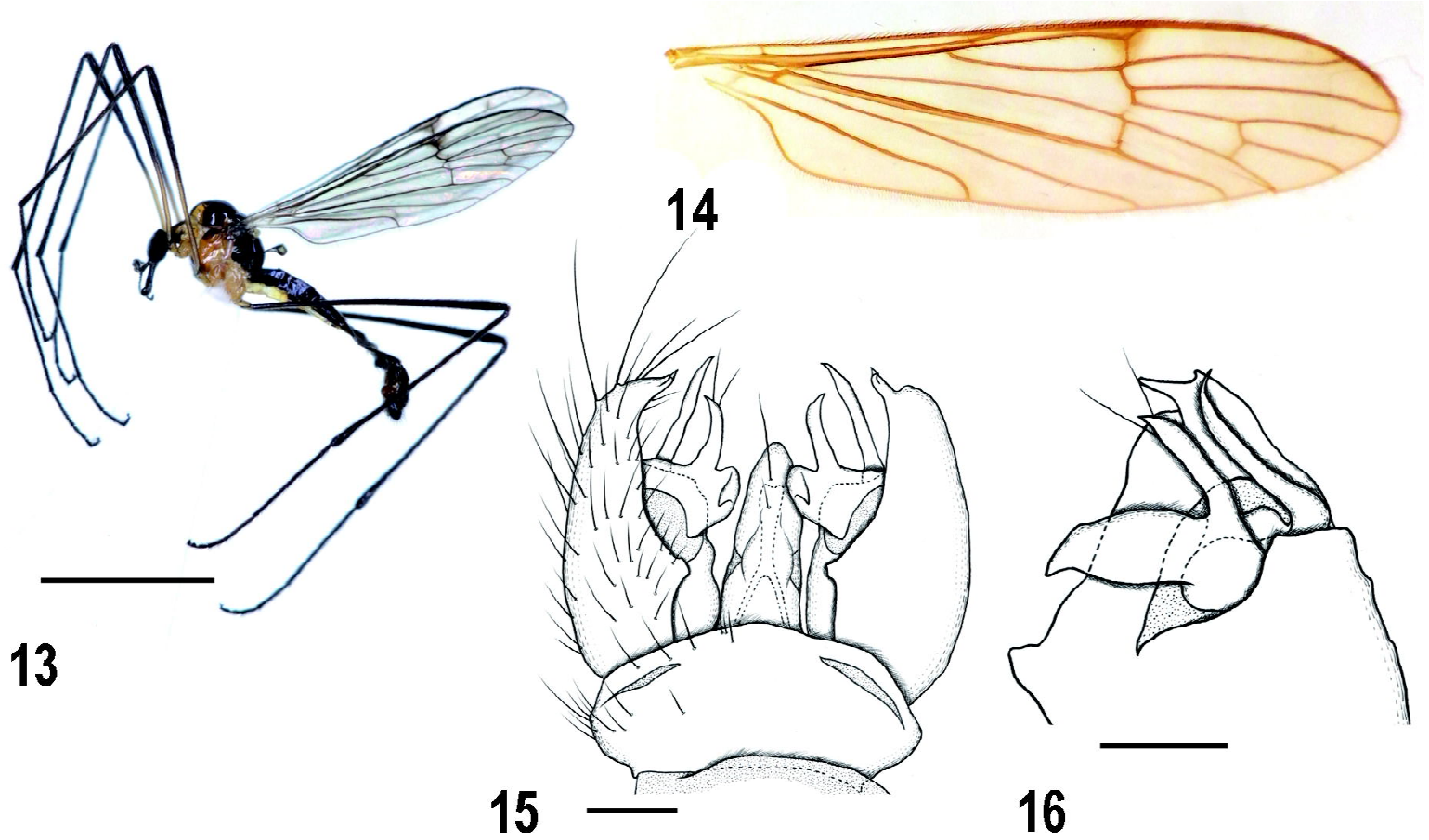

Figs 13-16. Teucholabis (Teucholabis) iriomotensis Alexander, 1935: 13 - habitus, male; 14 - wing; 15 - male genitalia, dorsal view; $16-$ gonocoxite, inner surface (left = dorsal). Scale bar: $13-3 \mathrm{mM}, 15,16-0,1 \mathrm{мм}$.

Рис. 13-16. Teucholabis (Teucholabis) iriomotensis Alexander, 1935: 13 - внешний виА, самец; 14 - wing; 15 - гениталии самџа, виА сверху; 16 - гонококсит, внутренняя поверхность (смева = дорсально). Масштаб: $13-3 \mathrm{~mm}, 15,16-0.1 \mathrm{~mm}$. 


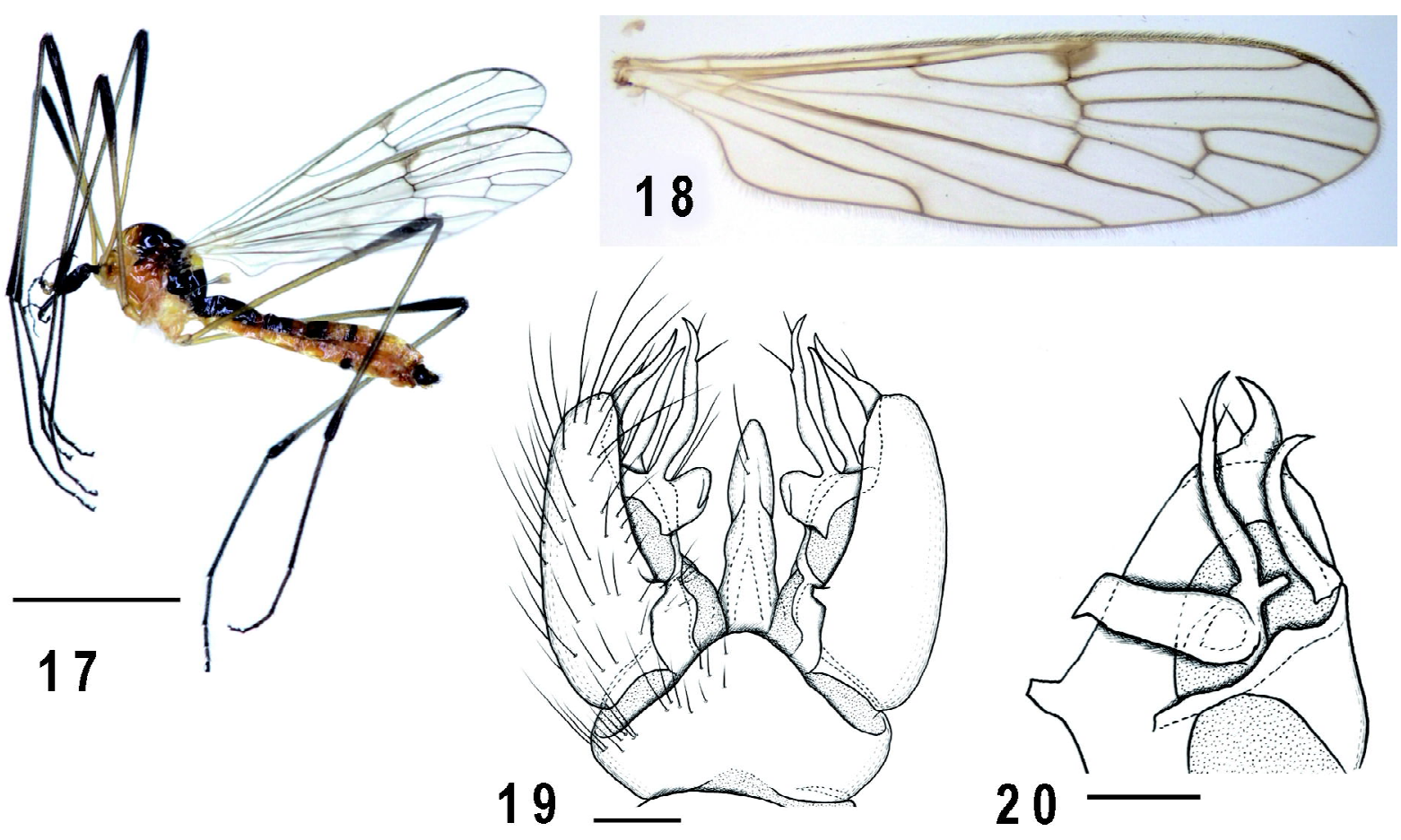

Figs 17-20. Teucholabis (Teucholabis) yezoensis Alexander, 1924: 17 - habitus, male; 18 - wing; 19 - male genitalia, dorsal view; $20-$ gonocoxite, inner surface (left = dorsal). Scale bar: $17-3 \mathrm{мм}, 19,20-0,1 \mathrm{мм}$.

Pис. 17-20. Teucholabis (Teucholabis) yezoensis Alexander, 1924: 17 - внешний виА, самец; 18 - крыло; 19 - гениталии самца, вид сверху; 20 - гонококсит, внутренняя поверхность (слева = дорсально). Масштаб: $17-3 \mathrm{~mm}, 19,20-0.1 \mathrm{~mm}$.

trally at tip; inner gonostylus bilobed, anterior lobe wide beakshaped, narrowed and weakly curved anteriorly on apical part, posterior lobe blade-shaped, about $1 / 3$ as wide as anterior lobe and about as long as anterior lobe, almost straight, acute at tip, with two setae near tip; aedeagus finger-shaped in dorsal view, middle of ventral part with projection directed posteriorly, tip of this projection not reaching at level of tip of aedeagus.

Female. Body length $6.5-7.6 \mathrm{~mm}$, wing length $4.6-5.2$ $\mathrm{mm}$. Resembling male in general appearance. Hind tibiae not widened. Each segment of sternites 2-7 with dark area on lateral side near middle; roundish swelling absent. Ovipositor slender; tergites 8 to 9 yellowish brown, tergite 10 dark brown, cylindrical; cercus reddish brown, weakly dark at base, about 1.5 times as long as tergite 10, weakly upcurved, subacute at tip; sternite 8 small, dark brown; hypogynial valve dark brown, weakly upcurved, basal part about as wide as sternite 8 , tip ending at level of distal $1 / 3$ of cercus.

Distribution. Japan (Nansei Islands: Iriomote-jima Is.).

Teucholabis (Teucholabis) yezoensis Alexander, 1924 Figs $17-20$.

Teucholabis yezoensis Alexander, 1924: 593. Type locality: Japan, Hokkaido, Shikaripetsu.

Teucholabis (Teucholabis) yezoensis: Nakamura [2014: 36]; Oosterbroek [2019].

Material. Holotype: 107, Japan: Hokkaido, Shikaripetsu, 26.VIII.1922, T. Esaki leg. (USNM). Paratypes: $10^{7}$, 19, same data as holotype. Non-types: [Honshu] 10', Aomori, Nishimeyamura, Kawaratai, Okawa-rindô Path, Alt. 300 m, 14.VIII.2013, D. Kato leg. (BLKU); 10 1 , 1 , same data as previous except 2.VIII.2014

Description. Male (Figs 17-20). Body length 6.8-7.2 $\mathrm{mm}$, wing length $6.2-7.0 \mathrm{~mm}$.
Head dark brown, yellowish on lateral side of posterior part, anterior part of vertex dusted with gray pruinosity; antenna dark brown, yellowish on basal two or three segments.

Thorax with pronotum yellow, antepronotum darkened at anterior margin, sometimes weakly darkened on center; mesonotum mainly shiny black; prescutum with large yellow area above humeral region, vaguely fused on anterior part, smaller ones at posterolateral corner and middle of posteror end; scutum yellow between scutal lobes and at posterior and inner margins of scutal lobe; scutellum entirely yellow; pleura mainly yellow, shiny black on laterotergite and weakly so on anterodorsal corner of anepisternum. Wing (Fig. 18) tinged with grayish yellow, stigma roundish, dark brown, anterior part of cord and outer end of cell d slightly seamed with brown, tip of $A_{1}$ weakly dark. Legs with coxae, trochanters, and femora yellow, gradually darkened to tip on distal $1 / 3$ of fore and mid femora and on distal $1 / 5$ of hind femur; tibiae dusky yellow, narrowly darkened at tips and weakly so at bases, tip of hind tibia weakly widened and flat; tarsi dark brown, sometimes brownish at bases of tarsomeres 1. Halter yellow on knob, dark brown on stem.

Abdomen with tergites mainly shiny dark brown to black, posterior margin of tergite 2 and anterior and posterior margins of tergites 3-7 yellow, these yellow bands wider on posterior segments, dark areas on segment 5-7 sometimes indistinct, tergite 8 entirely yellow; sternites yellow, each segment of sternites $2-4$ sometimes bearing dark area near middle of lateral side; sternite 5 largely darkened on center, with hairy roundish swelling at middle; sternite 6 with pair of rows of setae; sternite 7 with roundish swelling 
on center. Male genitalia (Figs 19-20) yellow on segment 9 , dark brown on gonocoxite; tergite 9 triangular with rounded corner at caudal margin; gonocoxite with claw-shaped lobe at tip, curved dorsally, bearing one seta near base of dorsal margin, dorsal margin of gonocoxite with small squarish projection near base; outer gonostylus slender rod-shaped, curved ventrally on distal part, acute at tip; inner gonostylus bilobed, anterior lobe beak-shaped, angulated at posterodorsal corner, anterodorsal corner weakly produced into pointed lobe directed anteriorly, posterior lobe spineshaped, about $1 / 3$ as wide as anterior lobe and about 1.5 times as long as anterior lobe, weakly sinuous, acute at tip, with two setae near tip; aedeagus finger-shaped in dorsal view, middle of ventral part with projection directed posteriorly, tip of this projection not reaching at level of tip of aedeagus.

Female. Body length $8.2-9.0 \mathrm{~mm}$, wing length $6.3-7.0$ $\mathrm{mm}$. Resembling male in general appearance. Hind tibia not widened. Abdominal tergites mainly shiny dark brown, caudal margins of tergites 2-7 narrowly yellow; each segment of sternites 2-7 with dark area on lateral side near middle; roundish swelling absent. Ovipositor slender; tergites 8 to 9 yellowish, tergite 10 dark brown, cylindrical; cercus amber color, dark on basal half, about 1.5 times as long as tergite 10 weakly upcurved, subacute at tip; sternite 8 small, dark brown, yellow at anterior end; hypogynial valve dark brown, weakly upcurved, basal part about as wide as sternite 8 , tip ending at level of distal $1 / 3$ of cercus.

Distribution. Japan (Hokkaido, Honshu); Russian Far East.

\section{Key to JaPAnese SPecies of TeuCholabis}

1. Body including wing blackish except for orangish thorax (Figs 9-10) $T$. (T.) inornate

- Body mainly black with yellow parts, wing grayish tinged

2. Scutellum and middle of scutum black; wing tip widely dark (Fig. 6) T. (Eup.) inouei

- Scutellum and middle of scutum yellow; wing tip not distinctly dark

3. Tibiae and hind femura completely black (Fig. 13) .......... ... T. (T.) iriomotensis

- Tibiae and hind femora partly blackish anepisternum and ventral side of katepisternum dark (Fig. 1); male genitalia with posterior lobe of inner gonostylus shorter than anterior lobe (Fig. 4)

T. (Eup.) esaki

- Yellow areas on anterior part of prescutum weakly fused anteriorly; only anterodorsal corner of anepisternum dark (Fig. 17); male genitalia with posterior lobe of inner gonostylus much longer than anterior lobe (Fig. 20) .......

\section{Acknowledgement}

I am grateful to Jon Gelhaus (the Academy of Natural Science of Drexel University, Philadelphia, USA) for helping me examine specimens in USNM and to Floyd Shockley and Torsten Dikow (USNM) for allowing me to examine their specimens. I am also indebted to Akifumi Ogawa (Field Science Center for Northern Biosphere, Forest Research Station, WAKAYAMA Experimental Forest, Kozagawa-chô, Japan), Kojiro Esaki (Ishikawa Forest Experiment Station, Hakusan-shi, Japan), and So Shimizu (Graduate School of Agricultural Science, Kobe University, Kobe-shi, Japan) for providing me with valuable specimens.

\section{References}

Alexander C.P. 1924. New or little-known crane flies from northern Japan (Tipulidae, Diptera) // Philippine Journal of Science. Vol.24. P.531-611.

Alexander C.P. 1935. New or little-known Tipulidae from eastern Asia (Diptera). XXVI// Philippine Journal of Science. Vol.57. P.195-225.

Alexander C.P. 1947. Notes on the tropical American species of Tipulidae (Diptera). I. The genus Teucholabis Osten Sacken // Revista de Entomologia. Vol.17. P.375-400.

Alexander C.P. 1955. Undescribed species of Japanese craneflies (Diptera: Tipulidae). Part VIII // Annals of the Entomological Society of America. Vol.48. P.364-374.

Krivosheina M.G. 2009. On biology of limoniid flies of the genus Teucholabis Osten Sacken (Diptera, Limoniidae) with a description of immature stages of Teucholabis esakii (Alexander) and T. yezoensis Alexander // Entomological Review. Vol.89. P.91-98.

Cumming J.F., Wood D.M. 2017. Adult morphology and terminology // Kirk-Spriggs A.H., Sinclair B.J. (Eds). Manual of Afrotropical Diptera. Volume 1. Introductory chapters and keys to Diptera families. Suricata. Vol.4. South African National Biodiversity Institute. Pretoria. P.89-133.

Nakamura T. 2014. Family Limoniidae // Nakamura T., Saigusa T., Suwa M. (Eds): Catalogue of the Insects of Japan Volume 8 Diptera, Part 1 Nematocera-Brachycera Aschiza. Tuoka Shobo. Fukuoka. P.9-53.

Oosterbroek P. 2019. Catalogue of the Craneflies of the World (Diptera, Tipuloidea: Pediciidae, Limoniidae, Cylindrotomidae, Tipulidae). Version 18 Feb 2019. Online version at https://ccw.naturalis.nl/index.php

Osten Sacken C.R. 1860. New genera and species of North American Tipulidae with short palpi, with an attempt at a new classification of the tribe // Proceedings of the Academy of Natural Sciences of Philadelphia 1859. P.197-254

Riedel M.P. 1918. H. Sauters Formosa Ausbeute: Liriopidae (Ptychopteridae) und Nematocera Polyneura (Dipt.), IV // Annales Historico-Naturales Musei Nationalis Hungarici. Vol.16. P.315-320.

Schiner J.R. 1866. Bericht uber die von der Weltumseglungsreise der k. Fregatte Novara mitgebrachten Dipteren // Verhandlungen der Kaiserlich-Koniglichen ZoologischBotanischen Gesellschaft in Wien. Vol.16. P.927-934. 